\title{
Benchmarking physicochemical vs. vibrational descriptors in predicting odor receptor responses
}

Jan Soelter ${ }^{1}$, Stephan Gabler ${ }^{1,2}$, Taufia Hussain ${ }^{3}$, Silke Sachse ${ }^{3}$, Michael Schmuker ${ }^{1,2^{*}}$

From 1st International Workshop on Odor Spaces

Hannover, Germany. 4-7 September 2013

Abstract available at http://onlinelibrary.wiley.com/doi/

10.1002/minf.201300037/abstract [1].

\section{Authors' details}

${ }^{1}$ Theoretical Neuroscience, Institute of Biology, Dept. of Biology, Chemistry, Pharmacy, Freie Universität Berlin, Königin-Luise-Str. 1-3, D-14195 Berlin,

Germany. ${ }^{2}$ Bernstein Center for Computational Neuroscience Berlin,

Philippstr. 13, Haus 6, D-10115 Berlin, Germany. ${ }^{3}$ Max Planck Institute for

Chemical Ecology, Hans-Knöll-Straße 8, D-07745 Jena, Germany.

Published: 16 April 2014

\section{Reference}

1. Gabler S, Soelter J, Hussain T, Sachse S, Schmuker M: Physicochemical vs.

Vibrational Descriptors for Prediction of Odor Receptor Responses. Mol Inform 2013, 32:855-865.

doi:10.1186/2044-7248-3-S1-O6

Cite this article as: Soelter et al: Benchmarking physicochemical vs.

vibrational descriptors in predicting odor receptor responses. Flavour

2014 3(Suppl 1):06.

Theoretical Neuroscience, Institute of Biology, Dept. of Biology, Chemistry, Pharmacy, Freie Universität Berlin, Königin-Luise-Str. 1-3, D-14195 Berlin, Germany

Full list of author information is available at the end of the article
Submit your next manuscript to BioMed Central and take full advantage of:

- Convenient online submission

- Thorough peer review

- No space constraints or color figure charges

- Immediate publication on acceptance

- Inclusion in PubMed, CAS, Scopus and Google Scholar

- Research which is freely available for redistribution

Submit your manuscript at www.biomedcentral.com/submit

\section{() Biomed Central}

